\title{
PENERAPAN PROGRAM PERAWATAN SPIRITUAL UNTUK MENURUNKAN DEPRESI PADA PASIEN LEUKEMIA
}

\author{
Nia Rosliany*) \\ Dewi Irawaty**) \\ Riri Maria**) \\ *)Dosen Akademi Keperawatan RS Husada, Jakarta, 10730, Indonesia \\ *)Fakultas ilmu Keperawatan, Universitas Indonesia, Kampus UI Depok, 16426
}

\begin{abstract}
ABSTRAK
Peran perawat spesialis medikal bedah adalah sebagai caregiver, researcher, dan innovator yang diterapkan dalam mengelola kasus pasien kanker dengan pendekatan chronic illness trajectory model, penerapan evidence based nursing program perawatan spiritual pada pasien leukemia untuk menurunkan depresi, dan melakukan proyek inovasi tentang manajemen edukasi bagi pasien yang menjalani perawatan isolasi radioaktif Iodine 131 di Ruang Isolasi Radio Aktif (RIRA) RSK Dharmais. Konsep trajectory merupakan salah satu teori keperawatan yang akan membantu memberdayakan pasien dan caregiver karena memberikan perawatan yang sesuai dengan tahapan atau fase penyakit pasien serta berfokus pada perawatan paliatif. Perawatan paliatif merupakan salah satu area fokus perawat spesialis pada bidang perawatan kanker yang akan membantu meningkatkan kemandirian dan kualitas hidup pasien. Penerapan perawatan program spiritual bersifat non-ivasif, murah, aman, dan secara tehnis praktis dalam mengelola status depresi pasien. Edukasi dapat memperbaiki pemahaman pasien tentang radioterapi dan efek sampingnya sehingga dapat meningkatkan kualitas mutu pelayanan keperawatan.
\end{abstract}

Keywords: chronic illness trajectory model, program perawatan spiritual, edukasi

\begin{abstract}
The role of nurse medical surgical specialist is as caregiver, researcher, and innovator applied on nursing care of cancer patients that used the chronic illness trajectory model approach, application of evidence based nursing practise in spiritual care program on leukemia patients to reduce depression, and perform innovation group project on educational management for patients undergoing radioactive Iodine 131 in Radioactive Isolation Ward Dharmais Cancer Hospital. The trajectory concept is one of the nursing theories that assist patients and caregivers' empowerment to provide appropriate care in the stage and phase of patient's illness and focuses on palliative care. Palliative care is one of the focus areas of nurse specialist in the field of cancer care that will improve the patient's independence and quality of life. The application of spiritual care program is non-invasive, cheap, safe, and practically in managing the patient's depression status. Education could improve patients' understanding of radiotherapy and its side effects to improve the quality of nursing care
\end{abstract}

Keywords: chronic illness trajectory model, spiritual care program, education 


\section{PENDAHULUAN}

Diagnosis kanker atau kondisi medis serius lainnya serta penatalaksanaannya merupakan suatu pengalaman yang menimbulkan stress dan menyebabkan terjadinya peningkatan depresi pada seseorang. Depresi merupakan gangguan emosional yang sifatnya berupa perasaan tertekan, tidak merasa bahagia, sedih, merasa tidak berharga, tidak mempunyai semangat, tidak berarti dan pesimis terhadap hidup (Gheihman et al., 2016). Depresi merupakan penderitaan yang timbul akibat interaksi dari faktor biologis, psikologis dan sosial.

Depresi telah terjadi pada $16-22 \%$ dari seluruh pasien dengan kanker, dengan kejadian lebih tinggi pada mereka yang sudah didiagnosis lama (Gheihman et al., 2016). Penelitian yang dilakukan Mhaidat, Alzoubi, dan Alhusein (2009) di Jordania, mendapatkan bahwa dari 208 pasien kanker 51,9\% mengalami depresi dan terbagi atas depresi ringan $(18,75 \%)$, sedang $(22,1 \%)$, hingga berat $(11 \%)$. Depresi dilaporkan terjadi pada 25$33 \%$ pasien kanker non darah dan $50 \%$ terjadi pada pasien dengan leukemia. Gejala depresi ditemukan pada pasien- pasien yang baru didiagnosis leukemia akut dan yang mengalami relaps (kekambuhan) yaitu sekitar 17,8\%, dan $40,4 \%$ diantaranya mengalami depresi sedang dan berat (Gheihman et al., 2016).

Dampak psikologis suatu penyakit yang didiagnosis buruk seperti leukemia mungkin menyebabkan kesedihan yang sangat mendalam. Perasaan tersebut muncul karena kecewa mengalami situasi yang sama sekali tak terduga dan tak diharapkan terjadi dalam hidupnya Kondisi ini dapat memberi dampak negatif pada pasien sendiri maupun keluarganya. Perasaan yang dialami pasien antara lain kekhawatiran akan masa depan, ketakutan menghadapi kematian, rasa nyeri dan penderitaan. Keinginan untuk bunuh diri di minggu pertama setelah didiagnosis kanker dengan prognosis buruk, 12 kali lipat lebih tinggi daripada populasi umum (Gheihman, et al., 2016). Depresi mempengaruhi tidak hanya status psikologi dan kualitas hidup pasien dengan kanker, tetapi juga berpengaruh terhadap kemajuan penyakit, efisiensi pengobatan, lamanya tinggal di rumah sakit (LOS), 
dan bahkan umur pasien sendiri. (Musarezaie et al, 2014).

Depresi pada pasien kanker masih belum banyak mendapatkan perhatian dari tenaga kesehatan di rumah sakit, sehingga penanganannya berpusat pada pemenuhan kebutuhan secara fisik, meskipun pada kenyataanya tanpa adanya depresi mampu meningkatkan kualitas pengobatan yang dijalani oleh pasien. Intervensi keperawatan yang dilakukan untuk masalah tersebut belum terlihat jelas, dimana asuhan keperawatan yang seharusnya bersifat holistik hanya terbatas pada aspek fisik saja, sehingga masalah psikologis pasien masih belum teratasi.

Para psikiater, dokter, dan psikolog telah melakukan berbagai upaya untuk menanggulangi gangguan depresi, seperti: psikoterapi, psikiatrik, psikofarmaka, terapi somatik, terapi relaksasi, dan terapi perilaku namun mereka juga mengakui bahwa diharapkan ada bentuk terapi yang lebih maksimal dapat menanggulangi depresi. Oh \& Kim (2014) menyatakan keyakinan spiritual atau keagamaan merupakan cara yang dapat ditawarkan untuk dapat membantu seseorang mengatasi berduka terhadap kematian yang akan datang, dengan menemukan makna, tujuan hidup di sekeliling teman-temannya dan keluarga yang dicintainya.

Spiritual dipandang sebagai sebuah konsep yang unik yang berhubungan dengan kualitas hidup (Yong et al, 2011). Beberapa hasil penelitian telah memberikan pembuktian mengenai hal tersebut. Oh dan Kim (2014) mengemukakan bahwa intervensi spiritual memiliki efek yang signifikan tetapi moderat terhadap kesejahteraan mental, makna hidup, dan depresi. Penelitian lainnya juga melaporkan bahwa intervensi berbasis spiritualitas dapat mengurangi depresi dan terlibat dalam hasil kesehatan (Rezaei et al, 2009 ; Mauk \& Scnemidt, 2004).

Kedua hasil penelitian diatas mendukung pandangan James (Carnegie, 1980 dalam Razak, Mokhtar, Sharazad, \& Sulaiman, 2013) bahwa terapi yang terbaik bagi keresahan adalah keimanan kepada Tuhan. Keimanan kepada Tuhan merupakan kekuatan yang tidak boleh tidak harus dipenuhi untuk menopang seseorang dalam hidup ini. 
Sementara itu David B. Larson dan Mr. Constance P. B, juga menyebutkan bahwa ditemukan bukti bahwa faktor keimanan memiliki pengaruh yang luas dan kuat terhadap kesehatan. Dalam tesisnya, the Faith Factor: Annotated Bioliography of Chemical Research on Spiritual Subject, mereka menemukan bahwa faktor spiritual terlibat dalam peningkatan kemungkinan tambahnya usia harapan hidup, penurunan pemakaian alkohol, rokok dan obat penurunan kecemasan, depresi dan kemarahan, penurunan tekanan darah, dan perbaikan kualitas hidup bagi pasien kanker serta penyakit jantung (Razak et al., 2013).

Perawat sebagai tenaga kesehatan yang memiliki kontak paling sering dengan pasien hendaknya peka dan dapat memberikan intervensi keperawatan terhadap masalah psikologis yang dihadapi pasien kanker. Terapi spiritual sangat berpengaruh untuk membangun rasa penerimaan diri (self acceptance) sehingga klien tidak merasa depresi lagi dan menyesali nasibnya. Bahkan sebaliknya klien akan mampu mengekspresikan perasaannya kepada kehidupan dan kesehatan mental yang lebih baik.

Pendekatan spiritual berperan penting dalam mengekspresikan perasaan dan memberikan kenyamanan bagi klien. Penerimaan keadaan sakit klien akan mendorong individu tersebut akan lebih dekat dengan Tuhan dan menerima penyakitnya sebagai cobaan dari Tuhan.

Fenomena menunjukkan kolaborasi dengan psikologis dan rohaniawan masih sangat kurang bahkan selama praktik residensi 1,2 dan 3 hanya beberapa pasien rawat inap yang mendapatkan intervensi untuk masalah psikologis mereka.

\section{METODE}

Langkah awal penerapan EBN dimulai dengan menumbuhkan semangat penelitian sehingga tertarik terhadap pertanyaan-pertanyaan yang berkaitan dengan perawatan pasien. Kemudian hasil penemuan mengenai fenomena di klinik selama praktik residensi dirumuskan dalam bentuk pertanyaan klinis dalam format PICO untuk menghasilkan evidenced yang lebih baik dan relevan. Dengan format PICO dapat menelusuri 
artikel-artikel yang relevan dengan pertanyaan klinis. Artikel yang dipilih adalah yang paling relevan, valid, terpercaya, dan berlaku untuk pertanyaan klinis.

Setelah menentukan salah satu artikel yang dipilih, lalu melakukan critical appraisal untuk mengetahui kelayakan artikel tersebut dan dijadikan dasar dalam penerapan EBN. Selanjutnya dilakukan penyusunan proposal EBN dan dikonsultasikan dengan pembimbing akademik dan pembimbing klinik untuk mendapatkan masukanmasukan guna menyempurnakan proposal dan dapat dengan mudah diterapkan. Setelah penulis mendapat persetujuan dari kedua pembimbing, maka dilakukan sosialisasi dengan bentuk presentasi proposal di hadapan pembimbing akademik, pembimbing klinik, bidang keperawatan (clinical case manager dan komite keperawatan), kepala ruang, dan primary nurse rawat inap, termasuk ruang isolasi imunitas menurun (RIIM) pada tanggal 11 April 2017. Kegiatan ini dimaksudkan untuk mendapatkan masukan dan saran sehingga EBN yang direncanakan dapat diterapkan di area kliniknya.
Lalu peneliti mempersiapkan segala sesuatunya perlengkapan yang dibutuhkan untuk pelaksanaan EBN seperti mp3, tasbih, dan perlengkapan sholat, formulir demografi, formulir pengkajian DASS depresi 42, dan informed consent. Selanjutnya peneliti meminta persetujuan responden untuk terlibat dalam penelitian. Jika responden setuju maka responden diminta untuk menandatangani surat persetujuan menjadi responden.

Pelaksanaan EBN dilakukan di ruang rawat inap teratai dan melati RSK Dharmais, dimulai pada tanggal 17 April - 5 Mei 2017. Kemudian dilakukan identifikasi pasien yang cocok sesuai dengan kriteria inklusi, yaitu bersedia ikut serta dalam pelaksanaan EBN dengan mengisi informed consent, didiagnosis keganasan darah dengan melihat diagnosis di status pasien dan dilaporkan mengalami depresi, subjek adalah pasien dewasa. Sementara subjek tidak dilibatkan dalam penerapan EBN jika pasien tidak peduli dengan status kesehatannya sehingga menyulitkan untuk dilakukan intervensi, mengalami retardasi mental, buta, tuli atau mengalami gangguan mental. Sebelum pelaksanaan EBN pasien diberikan 
dulu informasi tentang tujuan, manfaat dan prosedur pelaksanaan EBN. Pasien yang setuju terlibat dalam pelaksanaan EBN menandatangani lembar informed consent.

Prosedur diawali dengan pengukuran subskala depresi DASS-42 pada pasien. Supaya penerapan intervensi EBN dipahami oleh peneliti karena seiman, maka peneliti memprioritaskan pasien-pasien yang beragama islam. Untuk memperlancar kegiatan ibadahnya, pasien diberikan bingkisan yang berisi mukena, tasbih dan mp3. Selanjutnya memberikan dukungan pada pasien saat melakukan ritual keagamaan seperti sholat atau berdoa, dzikir, dan mendengarkan alunan ayat suci al qur'an melalui mp3. Peneliti juga mendorong pasien untuk mengekspresikan perasaanya, kebutuhan dan kekhawatiran melalui komunikasi verbal dan non verbal, memberikan penjelasan tentang penyakit mereka dan proses terapi kepada pasien secara rinci, dan memberikan tehnik sentuhan atau menjadi pendengar yang baik. Peneliti memanggil pasien dengan nama yang mereka sukai selama intervensi. Kemudian melakukan kembali pengukuran DASS pada hari ke-3 setelah pemberian intervensi berturutturut selama 3 hari.

\section{HASIL}

Sebanyak 10 orang pasien terlibat dalam penerapan EBN sampai akhir. Berikut ini karakteristik dan hasil penerapan EBN yang dilakukan pada pasien.

Dari 10 subjek penelitian, setengahnya (5 orang) berpendidikan diploma, 2 (dua) orang tamatan SD, 1 (satu) orang SLTP, 2 (dua) orang SLTA. Jenis kelamin pasien yang terlibat dalam penerapan EBN adalah sama, 5 (lima) orang laki-laki, dan 5 (lima) orang perempuan. Status perkawinan pasien yang terlibat dalam penerapan EBN mayoritas sudah menikah yaitu 8 (delapan) orang, dan 2 (dua) orang belum menikah. Jenis pekerjaan pasien yang terlibat dalam penerapan EBN bervariasi yaitu sebagai guru 1 (satu) orang, PNS 2 (dua) orang, wiraswasta 2 (dua) orang, ojek motor 1(satu) orang, petani 1 (satu) orang, dan masih mahasiswa 1 (satu) orang, sedangan 2 (dua) orang tidak bekerja atau sebagai ibu rumah tangga.

Rata-rata pasien yang terlibat dalam penerapan EBN ini berusia 43 tahun dengan standar deviasi 11,3 tahun. Usia pasien yang paling rendah adalah 
25 tahun, dan paling tinggi 63 tahun.

Lamanya pasien yang terlibat dalam penerapan EBN terdiagnosis leukemia rata-rata 5,9 bulan dengan standar deviasi 4,77. Yang masih baru terdiagnosis leukemia rata-rata adalah 2,48 bulan, dan yang paling lama terdiagnosis leukemia rata-rata 9,31 bulan.

Berdasarkan hasil uji distribusi frekuensi DASS-42 depresi pada kelompok eksperimen, didapatkan hasil bahwa mean post lebih kecil (12) dibandingkan mean pre (16) sehingga dapat disimpulkan, ada penurunan skala depresi (4) sebelum dan setelah dilakukan program perawatan spiritual. Sedangkan pada kelompok kontrol mean post juga lebih kecil yaitu (16) dibandingkan mean pre (17), namun penurunan skala depresi hanya sedikit yaitu 1 (satu) dibandingkan kelompok eksperimen yaitu 4 (empat). Dengan demikian dapat disimpulkan bahwa program perawatan spiritual dapat menurunkan rata-rata skala depresi menjadi 12 (4) di kelompok eksperimen.

\section{PEMBAHASAN}

Selama proses penerapan atau pelaksanaan EBN, penulis tidak menemukan kendala atau hambatan yang berarti. Kendala yang ada adalah sulitnya mengajak salah satu klien untuk melaksanakan sholat, sebagai salah satu program keperawatan spiritual. Namun setelah dikaji, ada beberapa faktor yang menjadi hambatan klen untuk menjalankan ibadah spiritualnya, khususnya melaksanakan sholat 5 waktu. Faktor pertama terkait dengan budaya di keluarga klien, dimana klien dan suaminya jarang melakukan sholat 5 (lima) waktu, dengan alasan kesibukan di sawah menyebabkan waktunya untuk beribadah menjadi banyak tersita. Namun keluarganya menyadari bahwa sebenarnya hal ini harusnya tidak boleh terjadi karena sholat 5 waktu merupakan kewajiban yang tidak boleh diabaikan.

Faktor kedua adalah kondisi kliennya sendiri, dimana saat penerapan intervensi EBN klien dalam kondisi yang tidak nyaman, seperti adanya mual, muntah dan lemas. Kondisi ini tentunya membuat klien malas untuk melakukan aktifitasnya, termasuk 
menjalankan ibadah sesuai perintah agamanya. Dengan kurangnya hal ini membuat kondisi kejiwaan klien tambah berat. Dimana klien tidak memperoleh ketenangan bathinnya, yang seharusnya bisa didapatkan dengan cara memasrahkan diri terhadap Tuhannya. Dalam situasi ini upaya yang sudah dilakukan penulis adalah bersikap empati, memberi sentuhan, meluangkan waktu lebih sering berada di dekat klien dengan memberikan intervensi-intervensi keperawatan yang membuat klien senang dan nyaman, seperti memberikan pijatan di tangan dan punggungnya saat klien mual, selalu berusaha siap memberi bantuan saat klien membutuhkan seperti misalnya membantu eliminasi klien. Awalnya klien menolak karena malu dan ada suami yg selalu membantunya, tetapi dengan menunjukkan itikad baik dan ketulusan untuk membantu akhirnya klien mau menerima kehadiran penulis, sehingga dalam beberapa hari sudah bisa terbina hubungan atas dasar kepercayaan, sehingga klien kooperatif terhadap tindakan keperawatan yang diberikan untuk kebaikan klien. Diawali dengan hal-hal ringan seperti klien mau dianjurkan untuk berdzikir saat kondisinya merasa tidak nyaman karena mual, klien juga bersedia saat ditawarkan untuk mendengarkan murotal al qur'an dari mp 3 saat hatinya gelisah, dan di hari ke-6, klien mau menjalankan sholat dzuhur dengan difasilitasi penulis untuk perlengkapan sholatnya. Sedangkan untuk klien lainnya yang ikut dalam penelitian ini, penulis tidak menemukan hambatan yang berarti, karena klien-klien lainnya memang sudah biasa menjalankan ritual keagamannya, penulis hanya cukup memberi dukungan dan memfasilitasi saja, dengan melibatkan perawat ruangan dan keluarga klien.

\section{DAFTAR PUSTAKA}

Gheihman, G., Zimmermann, C., Deckert, A., Fitzgerald, P., Mischitelle, A., Rydall, A., ... Rodin, G. (2016). Depression and hopelessness in patients with acute leukemia: the psychological impact of an acute and life-threatening disorder. Psycho-Oncology, (September 2015), $\quad 979-\quad 989$. doi:10.1002/pon.3940

Grimsbo, G. H., Ruland, C. M., \& Finset, A. (2012). Cancer patients' expressions of emotional cues and concerns and oncology nurses' responses, in an online patient-nurse communication service. Patient education and counseling, 88(1), 36-43. doi:10.1016/j.pec.2012.01.007. 
Jafari et al. (2013) Spiritual therapy to improve the spiritual wellbeing of iranian women with breast cancer ; a randomized controlled trial. Hindawi publishing corporation. 2013

Liu CJ, Hsiung PC, Chang KJ, Liu YF, Wang KC, Hsiao $\mathrm{FH}$, et $a l$. A study on the efficacy of body-mind-spirit group therapy for patients with breast cancer. J Clin Nurs 2008;17:2539-49.

Mauk K, Scnemidt N. Spirituality Care in Nursing Practice. 2th ed. Philadelphia: Lippincott Company; 2004. p. 60-199

Montgomery C, Pocock M, Titley K, Lloyd K. Predicting psychological distress in patients with leukaemiaand lymphoma. J Psychosom Res 2003;54:289-92.

Musarezaine A, Moeini M, Taleghani F, Mehrabi T. Does spiritual care program affect levels of depression in patients with leukemia? A randomized clinical trial. Journal of Education and Health Promotion, Vol 3. 2014

Pascoe, S.W., Neal, R. D., Allgar, V. L., Selby, P. J., Wright, E. P., (2004). Psychosocial care for cancer patients in primary care ? Recognition of opportunities for cancer care. Journal of Family Practise, 2 (4) 437-
442.

Pok-Ja Oh \& Kim Hyun. The effects of spiritual intervention in patients with cancer ; a metaanalysis. Oncology Nursing forum. Vol.41, No 5. 2014

Rajagopal D, Mackenzie E, Bailey C, Lavizzo-Mourey R. The effectiveness of a spirituallybased intervention to alleviate subsyndromal anxiety and minor depression among older adults. J Relig Health 2002;41:153-66

Rezaei M, Seyedfatemi N, Hosseini F. Spiritual well-being in cancer patients who undergo chemotherapy. J Fac Nurs Midwifery 2009;14:33-9.

Yong J, Juhu K, Park J, Seo I, Swinton J. Effects of a spirituality Training Program on The Spiritual and Psychosocial Well-Being of Hospital Middle Manager Nurses in Korea. The Journal of Continuing Education in Nursing. Vol 42;6. 2011 